\title{
Association of $P 2 X 7$ gene polymorphisms with susceptibility to pulmonary tuberculosis in Zahedan, Southeast Iran
}

G. Bahari ${ }^{1,2}$, M. Hashemi ${ }^{3,2}$, M. Taheri ${ }^{4}$, M. Naderi ${ }^{1}$, A. Moazeni-Roodi ${ }^{1}$, H.R. Kouhpayeh ${ }^{1}$ and E. Eskandari-Nasab ${ }^{2}$

${ }^{1}$ Research Center for Infectious Diseases and Tropical Medicine, Zahedan University of Medical Sciences, Zahedan, Iran ${ }^{2}$ Department of Clinical Biochemistry, School of Medicine, Zahedan University of Medical Sciences, Zahedan, Iran ${ }^{3}$ Cellular and Molecular Research Center, Zahedan University of Medical Sciences, Zahedan, Iran ${ }^{4}$ Genetic of Non-Communicable Diseases Research Center, Zahedan University of Medical Sciences, Zahedan, Iran

Corresponding author: M. Hashemi

E-mail: mhd.hashemi@gmail.com / hashemim@zdmu.ac.ir

Genet. Mol. Res. 12 (1): 160-166 (2013)

Received May 6, 2012

Accepted September 27, 2012

Published January 24, 2013

DOI http://dx.doi.org/10.4238/2013.January.24.8

ABSTRACT. Susceptibility to tuberculosis may be influenced by variations in human genes. The $P 2 X 7$ receptor is an ATP-gated cation channel expressed in immune cells, and it influences the release of proinflammatory cytokines from monocytes and macrophages. In the present study, we aimed to evaluate the impact of $P 2 X 7$ gene rs 2393799 $(-762 \mathrm{~T} / \mathrm{C})$ and rs1718119 (Thr348Ala) polymorphisms on patient susceptibility to pulmonary tuberculosis (PTB) in a sample of the Iranian population. This case-control study was performed using 150 PTB cases and 150 controls. $P 2 X 7$ receptor polymorphisms were determined using tetra-amplification refractory mutation system-polymerase chain reaction. Genotype and allelic frequencies of the rs2393799 variant 
within the $P 2 X 7$ gene were significantly higher in the PTB patients than in the healthy controls. The genotypes were $\mathrm{CC}$ in $71, \mathrm{CT}$ in 54 , and TT in 25 PTB patients. The genotypes were CC in 104, CT in 40, and TT in 6 healthy controls. The results indicate a significant association between rs2393799 polymorphism of the $P 2 X 7$ gene and susceptibility to PTB (CT vs CC: $\mathrm{OR}=6.5,95 \% \mathrm{CI}=2.5-16.9, \mathrm{P}<0.0001$; $\mathrm{TT}$ vs $\mathrm{CC}: \mathrm{OR}=3.3,95 \% \mathrm{CI}=1.2-8.9, \mathrm{P}=0.018 ; \mathrm{TC}+\mathrm{TT}$ vs $\mathrm{CC}: \mathrm{OR}=2.56$, $95 \% \mathrm{CI}=1.59-4.12, \mathrm{P}<0.0001)$. The rs $2393799 \mathrm{~T}$ allele is a risk factor for predisposition to $\mathrm{PTB}(\mathrm{OR}=2.53,95 \% \mathrm{CI}=1.73-3.71, \mathrm{P}<0.0001)$. No association between the rs1718119 polymorphism and PTB was found. In conclusion, the rs 2393799 polymorphism in the $P 2 X 7$ gene may contribute to patient susceptibility to PTB in our study population.

Key words: Tuberculosis; P2X7; Polymorphism

\section{INTRODUCTION}

Tuberculosis (TB) is the leading cause of morbidity and mortality worldwide, particularly in Asia and Africa (Kouhpayeh et al., 2012). In 2006, an estimated 9.2 million new cases of TB were reported globally, resulting in 1.7 million deaths, including those of 0.7 million new cases and 0.2 million HIV-positive individuals (World Health Organization, 2008). The $\mathrm{P} 2 \mathrm{X} 7$ receptor belongs to a family of ATP-gated nonselective cation channels ( $\left.\mathrm{P} 2 \mathrm{X}_{1-7}\right)$, which are highly permeable to $\mathrm{Na}^{+}, \mathrm{Ca}^{2+}$, and $\mathrm{K}^{+}$ions (Khakh and North, 2006). Human $P 2 X 7$, which encodes the P2X7 receptor, contains 13 exons and is localized on chromosome 12q24. It encodes a polypeptide that contains 595 amino acids, with 2 transmembrane domains (Sluyter and Stokes, 2011). Activation of P2X7 by adenosine triphosphate (ATP) causes the instantaneous opening of a cation channel, permitting the influx of $\mathrm{Ca}^{2+}$ and $\mathrm{Na}^{+}$and the efflux of $\mathrm{K}^{+}$. This process initiates a number of downstream signaling events, such as the caspase cascade, and results in apoptosis or activation of phospholipase $\mathrm{D}$, which promotes the phagosome-lysosome fusion and causes mycobacterial death (Humphreys et al., 2000; Kusner and Barton, 2001; CoutinhoSilva et al., 2003). $P 2 X 7$ is highly polymorphic, with several single nucleotide polymorphisms (SNPs) that affect the function of this receptor (Wiley et al., 2003; Gu et al., 2004; Fernando et al., 2005; Shemon et al., 2006; Haas et al., 2007; Ben-Selma et al., 2011; Singla et al., 2012).

Host genetic factors contribute substantially to the development of TB. For instance, ethnic and racial differences in the vulnerability of humans to TB with respect to $P 2 X 7 R$ polymorphisms have been reported (Li et al., 2002; Fernando et al., 2007; Nino-Moreno et al., 2007; Mokrousov et al., 2008; Xiao et al., 2009; Wang et al., 2011; Singla et al., 2012). Thus, we aimed to identify the possible association between $\mathrm{P} 2 \mathrm{X} 7$ polymorphisms and the risk of pulmonary tuberculosis (PTB) in a sample of the Iranian population.

\section{MATERIAL AND METHODS}

This case-control study was performed using $150 \mathrm{PTB}$ patients and 150 healthy subjects (controls). The diagnosis of PTB was based on clinical analysis, radiological analysis, sputum acid-fast bacillus smear positivity, cultures, and response to antituberculosis chemotherapy, as 
described previously (Naderi et al., 2009, 2010). The local Ethics Committee of the Zahedan University of Medical Sciences approved the project, and written informed consent was obtained from all participants. Genomic DNA was extracted from whole blood samples, as described previously (Hashemi et al., 2010a). SNP genotyping of $P 2 X 7 R$ was performed using tetra-amplification refractory mutation system-polymerase chain reaction (T-ARMS-PCR), which is a simple and rapid method for detecting SNP (Hashemi et al., 2010b, 2012). Two external primers (control band) and 2 inner primers (allele-specific primers) were used (Table 1). The product sizes for detection of rs 2393799 polymorphism were as follows: $156 \mathrm{bp}$ for the T allele, $219 \mathrm{bp}$ for the $\mathrm{C}$ allele, and $323 \mathrm{bp}$ for the control band (Figure 1A). For the $P 2 X 7 R$ rs1718119 polymorphism, the product sizes were as follows: $198 \mathrm{bp}$ for the A allele, $284 \mathrm{bp}$ for the $\mathrm{G}$ allele, and $435 \mathrm{bp}$ for the 2 outer primers (control band) (Figure 1B).

Table 1. Primers used for determination of rs 1718119 and rs 2393799 polymorphisms of $P 2 X 7$ receptor.

\begin{tabular}{lll}
\hline Primers & Thr348Ala $(\mathrm{rs} 1718119)$ & $-762 \mathrm{C} / \mathrm{T}(\mathrm{rs} 2393799)$ \\
\hline Forward inner & TTGTCTGCATTCTCCCCAGGACA & TGGTGTCCCTCACTGAATAGGTCCAT \\
Reverse inner & GATGAGGAAGTCGATGAACACCGC & AGTGGCAGTCCAACAAAGTTAGGTGTG \\
Forward outer & GTCACAGCATGAGGCTCCGCTC & TCTTTGCAATCCAGACTGAAGTTGACTG \\
Reverse outer & TGGTGTCCTGTGAACACAGCGG & CAGATCTTTCATGCTTGACCCTCTGAGT \\
\hline
\end{tabular}

A

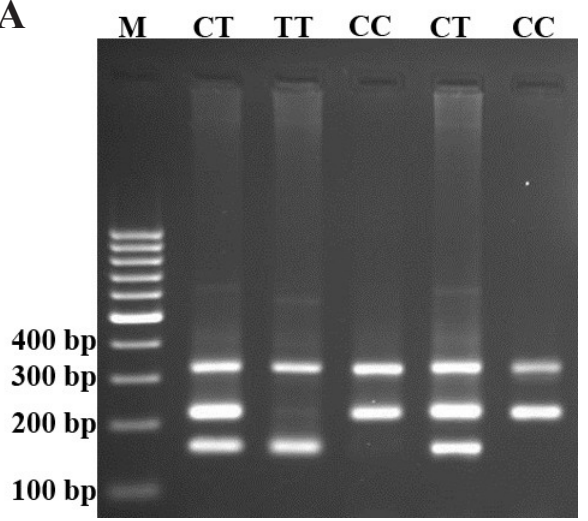

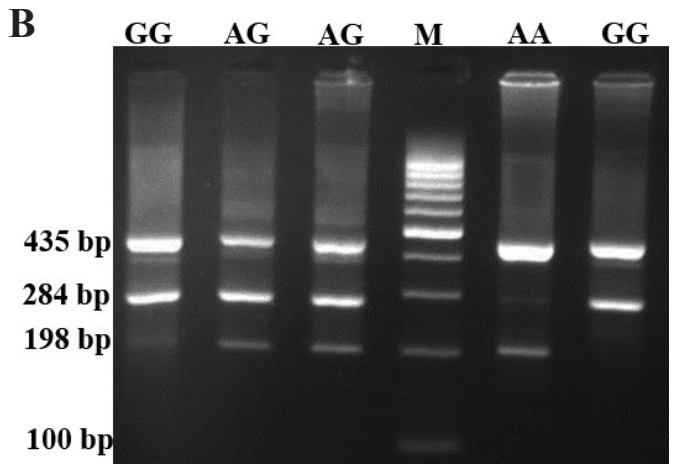

Figure 1. Photograph of tetra-amplification refractory mutation system-polymerase chain reaction (T-ARMS-PCR) for detection of rs2393799 (A) and rs1718119 (B) polymorphisms of the $P 2 X 7$ gene. Lane $M=$ DNA marker.

PCR was performed using a commercially available PCR premix (AccuPower PCR PreMix, Bioneer, Daejeon, South Korea), according to the recommended manufacturer protocol. In brief, $1 \mu \mathrm{L} \sim 100 \mathrm{ng} / \mu \mathrm{L}$ template DNA, $1 \mu \mathrm{L} 10 \mu \mathrm{M}$ of each primer and $15 \mu \mathrm{L}$ DNasefree water were added to a $0.2-\mathrm{mL}$ PCR tube that contained the AccuPower PCR Pre-Mix.

The PCR cycling conditions were as follows: $5 \mathrm{~min}$ at $95^{\circ} \mathrm{C}$, followed by 30 cycles of $30 \mathrm{~s}$ at $95^{\circ} \mathrm{C}$, then $30 \mathrm{~s}$ at $64^{\circ} \mathrm{C}$ for rs 1718119 or $25 \mathrm{~s}$ at $60^{\circ} \mathrm{C}$ for rs 2393799 , and $30 \mathrm{~s}$ at $72^{\circ} \mathrm{C}$, with a final step at $72^{\circ} \mathrm{C}$ for 10 min to allow for the complete extension of all PCR fragments. The PCR products were analyzed using electrophoresis on a $2 \%$ agarose gel that contained 0.5 $\mu \mathrm{g} / \mathrm{mL}$ ethidium bromide. Then, the products were visualized by transillumination with UV light, and photographs were taken by a Nikon camera. To validate the quality of genotyping, 
we reprocessed approximately $20 \%$ of the samples, resulting in $100 \%$ confirmation of the previous genotyping results.

\section{Statistical analysis}

Statistical analysis was performed using the SPSS 18.0 software. An independent sample $t$-test was used for continuous data, and a chi-square test was used for categorical data. The associations between genotypes and PTB were assessed by computing the odds ratio (OR) and $95 \%$ confidence intervals $(95 \% \mathrm{CI})$ from logistic regression analyses.

\section{RESULTS}

In the study, we recruited 150 PTB patients (male/female: 57/93; mean age: $48.97 \pm 21.2$ years) and 150 healthy individuals (male/female: $51 / 99$; mean age: $45.36 \pm 16.1$ years). No significant difference was found between the groups with respect to gender and age $(\mathrm{P}=0.274$ and $\mathrm{P}=$ 0.097, respectively).

Genotypic and allelic frequencies of $P 2 X 7 R$ polymorphisms were compared between PTB and normal subjects (Table 2). The results showed that there was a significant difference between the groups with respect to rs2393799 polymorphism $\left(\chi^{2}=19.9, \mathrm{P}<0.0001\right)$.

\begin{tabular}{|c|c|c|c|c|c|c|}
\hline Polymorphism & РТВ & Normal & OR $(95 \% \mathrm{CI})$ & $\mathrm{P}$ & OR $(95 \% \mathrm{CI})^{\mathrm{a}}$ & $\mathrm{P}$ \\
\hline \multicolumn{7}{|l|}{ rs2393799 } \\
\hline $\mathrm{CC}$ & $71(47.3)$ & $104(69.3)$ & Reference & - & & \\
\hline CT & $54(36.0)$ & $40(26.7)$ & $6.10(2.40-15.6)$ & $<0.0001$ & $6.5(2.5-16.9)$ & $<0.0001$ \\
\hline TT & $25(16.7)$ & $6(4.0)$ & $3.10(1.20-8.21)$ & 0.024 & $3.3(1.2-8.9)$ & 0.018 \\
\hline $\mathrm{CT}+\mathrm{TT}$ & $79(52.7)$ & $46(30.7)$ & $2.52(1.57-4.04)$ & $<0.0001$ & $2.56(1.59-4.12)$ & $<0.0001$ \\
\hline \multicolumn{7}{|l|}{ Allele } \\
\hline $\mathrm{C}$ & $196(65.3)$ & $248(82.7)$ & & & & \\
\hline $\mathrm{T}$ & $104(34.7)$ & $52(17.3)$ & $2.53(1.73-3.71)$ & $<0.0001$ & & \\
\hline \multicolumn{7}{|l|}{ rs1718119 } \\
\hline GG & $63(42.0)$ & $66(44.0)$ & Reference & - & Reference & - \\
\hline $\mathrm{GA}$ & $72(48.0)$ & $69(46.0)$ & $0.92(0.56-1.47)$ & 0.715 & $0.91(0.56-1.47)$ & 0.694 \\
\hline $\mathrm{AA}$ & $15(10.0)$ & $15(10.0)$ & $0.96(0.43-2.11)$ & 0.909 & $1.00(0.45-2.26)$ & 0.977 \\
\hline $\mathrm{GA}+\mathrm{AA}$ & $87(58.0)$ & $84(56.0)$ & $1.08(0.69-1.71)$ & 0.726 & $1.08(0.68-1.71)$ & 0.741 \\
\hline \multicolumn{7}{|l|}{ Allele } \\
\hline G & $198(66.0)$ & $201(67.0)$ & & & & \\
\hline A & $102(34.0)$ & $99(33.0)$ & $1.05(0.74-1.46)$ & 0.867 & & \\
\hline
\end{tabular}

The findings showed that the $\mathrm{CT}$ and $\mathrm{TT}$ genotypes were a risk factor for predisposition to $\mathrm{PTB}\left(\mathrm{CT} v_{s} \mathrm{CC}: \mathrm{OR}=6.5,95 \% \mathrm{CI}=2.5-16.9, \mathrm{P}<0.0001\right.$; $\mathrm{TT} v_{s} \mathrm{CC}: \mathrm{OR}=3.3,95 \% \mathrm{CI}$ $=1.2-8.9, \mathrm{P}=0.018 ; \mathrm{TC}+\mathrm{TT}$ v $\mathrm{CC}: \mathrm{OR}=2.56,95 \% \mathrm{CI}=1.59-4.12, \mathrm{P}<0.0001)$. Furthermore, we found that the rs2393799 $\mathrm{T}$ allele was a risk factor for predisposition to $\mathrm{PTB}(\mathrm{OR}=2.53$, $95 \% \mathrm{CI}=1.73-3.71, \mathrm{P}<0.0001)$.

Concerning rs 1718119 polymorphism, the genotypes were GG in 63 , GA in 72 , and AA in 15 PTB patients. The genotypes were GG in 66, GA in 69, and AA in 15 healthy controls. We did not observe significant differences between the case and control groups with respect to the rs1718119 genotype or allelic frequencies $(\mathrm{P}>0.05)$. 
In normal subjects, the rs2393799 and rs1718119 genotypes were found to be in Hardy-Weinberg equilibrium (HWE; $\chi^{2}=0.72, \mathrm{P}=0.39$ and $\chi^{2}=0.24, \mathrm{P}=0.62$, respectively). While in PTB patients, the rs1718119 genotype $\left(\chi^{2}=0.72, \mathrm{P}=0.39\right)$, but not the rs 2393799 genotype $\left(\chi^{2}=6.3, \mathrm{P}=0.01\right)$, was in HWE.

\section{DISCUSSION}

In the present study, we examined the possible association between $P 2 X 7 R$ polymorphisms -762C/T (rs2393799) and Thr348Ala (rs1718119) with the risk of PTB in a sample of the Iranian population. Our finding showed that the $-762 \mathrm{C} / \mathrm{T}$ polymorphism is a risk factor for PTB. We found no significant difference between PTB and normal subjects with respect to Thr348Ala polymorphism.

Our findings support those of Singla et al. (2012) and Li et al. (2002), who identified a significant protective association between TB and the $-762 \mathrm{C}$ allele. We found that the $-762 \mathrm{~T}$ allele is a risk factor for PTB in our study population. In contrast to our findings, Sambasivan et al. (2010) found a significant difference between PTB patients and controls for the -762 C allele and reported that the $\mathrm{C}$ allele is a risk factor for PTB in the Asian Indian population. Xiao et al. (2009) found that the $-762 \mathrm{~T} / \mathrm{C}$ variant of P2X7 was not significantly associated with TB in the Chinese Han population. While a significant association was found between the $1513 \mathrm{~A} / \mathrm{C}$ variant of $P 2 X 7$ and PTB, no association was found between the $-762 \mathrm{~T} / \mathrm{C}$ polymorphism and TB in the Mexican mestizo population (Nino-Moreno et al., 2007) or the Russian Caucasian population (Mokrousov et al., 2008). Researchers from Australia have found an association between the $1513 \mathrm{C}$ allele and extrapulmonary TB, rather than PTB, in the Australian Vietnamese population (Fernando et al., 2007).

Purinergic P2X7 receptors are cationic channels that are present in cells in the blood and immune system and are highly expressed on mononuclear leukocytes (Gu et al., 2001). The P2X7 receptor is activated by extracellular ATP, which causes a cation-selective channel to open, leading to an influx of $\mathrm{Ca}^{2+}$ and induction of the caspase cascade. This process results in apoptosis or autophagy and the killing of intracellular Mycobacterium tuberculosis (Wang et al., 2011). The $P 2 X 7$ gene is highly polymorphic, and polymorphisms in the promoter or coding region may modify its expression or function. A polymorphism in the promoter region, such as $-762 \mathrm{~T} / \mathrm{C}$, could affect the level of $P 2 X 7$ expression by altering the binding of a transcription factor. Li et al. (2002) observed that the expression of the P2X7 receptor on the mononuclear cells of Gambian patients with active TB was reduced and that the expression levels recovered during chemotherapy.

An SNP in exon 13 of the $P 2 X 7$ receptor gene at +1513 position (Glu496Ala) has been shown to eradicate the function of this receptor and to be associated with increased susceptibility to TB in some ethnic groups (Sharma et al., 2010). The meta-analysis of 6 studies that involved 2525 subjects proposed that the $P 2 X 7$ receptor A1531C polymorphism is not associated with susceptibility to PTB (Wang et al., 2011). However, another meta-analysis study showed that polymorphisms at the 1513 locus had a statistically significant association with P2X7 variants and TB susceptibility, while the -762 locus allele variants were not significantly associated with $P 2 X 7$ variants and TB susceptibility (Xiao et al., 2010).

While environmental factors are important for the development of active $\mathrm{TB}$, there is convincing evidence concerning the genetic component in vulnerability to TB. Numerous 
susceptibility alleles that influence macrophage responses to mycobacteria have been documented (Hashemi et al., 2011). The loss of functional polymorphisms in the human $P 2 X 7$ gene may affect the capacity of macrophages to kill M. tuberculosis (Britton et al., 2007) and is a risk factor for predisposition to TB.

To the best of our knowledge, this is the first report regarding the impact of nonsynonymous SNP Ala348Thr in $P 2 X 7$ on PTB susceptibility. In conclusion, the results of this study showed that the $-762 \mathrm{C} / \mathrm{T}$ polymorphism, but not Ala348Thr, of the $P 2 R X 7$ gene influences susceptibility to PTB in a sample of the Iranian population.

\section{ACKNOWLEDGMENTS}

Research supported by a research grant from Zahedan University of Medical Sciences, Iran. The authors thank the patients and healthy subjects who willingly participated in the study.

\section{REFERENCES}

Ben-Selma W, Ben-Kahla I, Boukadida J and Harizi H (2011). Contribution of the $P 2 X 71513 \mathrm{~A} / \mathrm{C}$ loss-of-function polymorphism to extrapulmonary tuberculosis susceptibility in Tunisian populations. FEMS Immunol. Med. Microbiol. 63: 65-72.

Britton WJ, Fernando SL, Saunders BM, Sluyter R, et al. (2007). The genetic control of susceptibility to Mycobacterium tuberculosis. Novartis Found. Symp. 281: 79-89.

Coutinho-Silva R, Stahl L, Raymond MN, Jungas T, et al. (2003). Inhibition of chlamydial infectious activity due to P2X7R-dependent phospholipase D activation. Immunity 19: 403-412.

Fernando SL, Saunders BM, Sluyter R, Skarratt KK, et al. (2005). Gene dosage determines the negative effects of polymorphic alleles of the $P 2 X 7$ receptor on adenosine triphosphate-mediated killing of mycobacteria by human macrophages. J. Infect. Dis. 192: 149-155.

Fernando SL, Saunders BM, Sluyter R, Skarratt KK, et al. (2007). A polymorphism in the $P 2 X 7$ gene increases susceptibility to extrapulmonary tuberculosis. Am. J. Respir. Crit. Care Med. 175: 360-366.

Gu BJ, Zhang W, Worthington RA, Sluyter R, et al. (2001). A Glu-496 to Ala polymorphism leads to loss of function of the human P2X7 receptor. J. Biol. Chem. 276: 11135-11142.

Gu BJ, Sluyter R, Skarratt KK, Shemon AN, et al. (2004). An Arg307 to Gln polymorphism within the ATP-binding site causes loss of function of the human P2X7 receptor. J. Biol. Chem. 279: 31287-31295.

Haas SL, Ruether A, Singer MV, Schreiber S, et al. (2007). Functional P2X7 receptor polymorphisms (His155Tyr, Arg307Gln, Glu496Ala) in patients with Crohn's disease. Scand. J. Immunol. 65: 166-170.

Hashemi M, Moazeni-Roodi AK, Fazaeli A, Sandoughi M, et al. (2010a). Lack of association between paraoxonase-1 Q192R polymorphism and rheumatoid arthritis in southeast Iran. Genet. Mol. Res. 9: 333-339.

Hashemi M, Moazeni-Roodi AK, Fazaeli A, Sandoughi M, et al. (2010b). The L55M polymorphism of paraoxonase-1 is a risk factor for rheumatoid arthritis. Genet. Mol. Res. 9: 1735-1741.

Hashemi M, Sharifi-Mood B, Nezamdoost M, Moazeni-Roodi A, et al. (2011). Functional polymorphism of interferongamma (IFN-gamma) gene $+874 \mathrm{~T} / \mathrm{A}$ polymorphism is associated with pulmonary tuberculosis in Zahedan, Southeast Iran. Prague Med. Rep. 112: 38-43.

Hashemi M, Moazeni-Roodi A, Bahari A and Taheri M (2012). A tetra-primer amplification refractory mutation systempolymerase chain reaction for the detection of rs8099917 IL28B genotype. Nucleosides Nucleotides Nucleic Acids 31: 55-60.

Humphreys BD, Rice J, Kertesy SB and Dubyak GR (2000). Stress-activated protein kinase/JNK activation and apoptotic induction by the macrophage $P 2 X 7$ nucleotide receptor. J. Biol. Chem. 275: 26792-26798.

Khakh BS and North RA (2006). P2X receptors as cell-surface ATP sensors in health and disease. Nature 442: 527-532.

Kouhpayeh HR, Hashemi M, Hashemi SA, Moazeni-Roodi A, et al. (2012). R620W functional polymorphism of protein tyrosine phosphatase non-receptor type 22 is not associated with pulmonary tuberculosis in Zahedan, southeast Iran. Genet. Mol. Res. 11: 1075-1081.

Kusner DJ and Barton JA (2001). ATP stimulates human macrophages to kill intracellular virulent Mycobacterium tuberculosis via calcium-dependent phagosome-lysosome fusion. J. Immunol. 167: 3308-3315. 
Li CM, Campbell SJ, Kumararatne DS, Bellamy R, et al. (2002). Association of a polymorphism in the $P 2 X 7$ gene with tuberculosis in a Gambian population. J. Infect. Dis. 186: 1458-1462.

Mokrousov I, Sapozhnikova N and Narvskaya O (2008). Mycobacterium tuberculosis co-existence with humans: making an imprint on the macrophage P2X(7) receptor gene? J. Med. Microbiol. 57: 581-584.

Naderi M, Hashemi M, Kouhpayeh H and Ahmadi R (2009). The status of serum procalcitonin in pulmonary tuberculosis and nontuberculosis pulmonary disease. J. Pak. Med. Assoc. 59: 647-648.

Naderi M, Hashemi M, Mehdizadeh A, Mehrabifar H, et al. (2010). Serum adenosine deaminase activity and the total antioxidant capacity of plasma in pulmonary tuberculosis and non-tuberculosis pulmonary disease. Turk. J. Med. Sci. 40: 701-706.

Nino-Moreno P, Portales-Perez D, Hernandez-Castro B, Portales-Cervantes L, et al. (2007). P2X7 and NRAMP1/SLC11 A1 gene polymorphisms in Mexican mestizo patients with pulmonary tuberculosis. Clin. Exp. Immunol. 148: 469-477.

Sambasivan V, Murthy KJ, Reddy R, Vijayalakshimi V, et al. (2010). $P 2 X 7$ gene polymorphisms and risk assessment for pulmonary tuberculosis in Asian Indians. Dis. Markers 28: 43-48.

Sharma S, Kumar V, Khosla R, Kajal N, et al. (2010). Association of P2X7 receptor $+1513(A \rightarrow C)$ polymorphism with tuberculosis in a Punjabi population. Int. J. Tuberc. Lung. Dis. 14: 1159-1163.

Shemon AN, Sluyter R, Fernando SL, Clarke AL, et al. (2006). A Thr357 to Ser polymorphism in homozygous and compound heterozygous subjects causes absent or reduced $P 2 X 7$ function and impairs ATP-induced mycobacterial killing by macrophages. J. Biol. Chem. 281: 2079-2086.

Singla N, Gupta D, Joshi A, Batra N, et al. (2012). Genetic polymorphisms in the $P 2 X 7$ gene and its association with susceptibility to tuberculosis. Int. J. Tuberc. Lung. Dis. 16: 224-229.

Sluyter R and Stokes L (2011). Significance of P2X7 receptor variants to human health and disease. Recent Pat. DNA Gene Seq. 5: 41-54.

Wang X, Xiao H, Lan H, Mao C, et al. (2011). Lack of association between the P2X7 receptor A1513C polymorphism and susceptibility to pulmonary tuberculosis: a meta-analysis. Respirology 16: 790-795.

Wiley JS, Dao-Ung LP, Li C, Shemon AN, et al. (2003). An Ile-568 to Asn polymorphism prevents normal trafficking and function of the human P2X7 receptor. J. Biol. Chem. 278: 17108-17113.

World Health Organization (2008). Global Tuberculosis Control: Surveillance, Planning, Financing. World Health Organization, Geneva.

Xiao J, Sun L, Jiao W, Li Z, et al. (2009). Lack of association between polymorphisms in the $P 2 X 7$ gene and tuberculosis in a Chinese Han population. FEMS Immunol. Med. Microbiol. 55: 107-111.

Xiao J, Sun L, Yan H, Jiao W, et al. (2010). Metaanalysis of $P 2 X 7$ gene polymorphisms and tuberculosis susceptibility. FEMS Immunol. Med. Microbiol. 60: 165-170. 